\title{
GUERRA Y LITERATURA EN EL NOMBRE DEL PADRE DE NELLEKE NOORDERVLIET
}

\author{
Manuel Sánchez Romero \\ Universidad de Sevilla
}

\begin{abstract}
RESUMEN
El objetivo principal del presente articulo es mostrar cómo la autora neerlandesa Nelleke Noordervliet trata el tema de la Segunda Guerra Mundial en su novela El nombre del padre (1993), ofreciendo por primera vez un punto de vista crítico con el ciudadano neerlandés, anclado en una visión muy negativa de los alemanes.
\end{abstract}

Palabras clave: Literatura neerlandesa, Nelleke Noordervliet, Segunda Guerra Mundial, Alemania, Países Bajos.

\section{ABSTRACT}

This article analyses one of the most important issues that appears in the novel written by the celebrated Dutch writer Nelleke Noordervliet "In the name of the father" (1993),: the Second World War and the consequences for the relationship between Germany and Holland, in particular the negative attitude of the Dutch people towards Germany.

Keywords: Dutch literature, Nelleke Noordervliet, Second World War, Germany, Holland.

La Segunda Guerra Mundial ha tenido para la literatura neerlandesa una repercusión muy importante. Este acontecimiento es considerado un punto de referencia esencial en la literatura y en la historia de los Países Bajos. Los estudios literarios diacrónicos han demostrado cómo han surgido numerosas reacciones literarias como consecuencia de una guerra que, además, tienen el conflicto bélico como tema central. ${ }^{1}$ El tema de la Segunda Guerra Mundial ha experimentado en la literatura neerlandesa un desarrollo considerable a lo largo de toda la segunda mitad del siglo XX y hasta nuestros días, del que se han ocupado numerosas investigaciones. ${ }^{2}$ El objetivo principal del presente artículo es mostrar cómo la autora

\footnotetext{
${ }^{1}$ En Alemania surgieron después de la Segunda Guerra Mundial tendencias como la literatura de escombros (Trümmerliteratur), la literatura del soldado repatriado (Heimkebrerliteratur), o la denominada literatura de desmonte (Kablschlagliteratur), entre otras.

${ }^{2}$ Dos investigaciones destacan en este sentido. En ellas se estudian distintas tendencias, como la literatura de la resistencia durante la Segunda Guerra Mundial o la literatura que aborda como tema central los actos de los colaboradores durante la guerra. Para el primer grupo temático es interesante leer el trabajo de Ton Anbeek, en el que se analiza la literatura
} 
neerlandesa Nelleke Noordervliet trata dicho tema de manera novedosa en su novela De naam van de vader ${ }^{3}$ (El nombre del padre, 1993), ofreciendo por primera vez un punto de vista crítico con el ciudadano neerlandés, anclado en una visión muy negativa de los alemanes a causa de la Segunda Guerra Mundial.

Nelleke Noordervliet, nacida en 1945, llegó a ser un personaje célebre en los Países Bajos durante los años 80 como miembro del Partido Socialista. A causa de su actividad política no empezó su producción literaria hasta una edad madura: su primera novela, Tine, of de dalen waar het leven woont (Tine, o los valles donde habita la vida, 1987), se publica cuando la autora cuenta con 42 años. Dicha obra se centra en la historia de Tine, la primera esposa del célebre autor neerlandés Multatuli (1820-1887), y en la que Noordervliet pretende matizar la imagen de víctima que dicha mujer llegó a tener para los lectores neerlandeses. Después de publicar varias novelas y obras de teatro, en las que siempre se propone profundizar en acontecimientos o personajes históricos, publica en 1993 la novela De naam van de vader (El nombre del padre), obra nominada en 1994 para el Premio de Literatura Europea, asimismo ganadora del prestigioso premio literario neerlandés Multatuli y que ha sido traducida a varios idiomas. Nuevamente la autora se propone el estudio crítico de un hecho histórico: la visión negativa que de los alemanes existe en la sociedad neerlandesa a causa de la Segunda Guerra Mundial.

Cabe señalar a este respecto que en la cosmovisión de Nelleke Noordervliet se observa una actitud crítica frente a un hecho que la autora considera peligroso: colectivizar la culpa. Se refiere en concreto a la atribución de responsabilidades en un acontecimiento histórico como la Segunda Guerra Mundial. Así, escribió en su obra Het oog van de engelt: "Ik verzet me tegen de geest van de massa. Wie draagt schuld in een massa? Wie is verantwoordelijk? Allen en dus niemand. Dat is het gevaar." 5

La autora critica ferozmente a la sociedad neerlandesa en este punto. Así lo expresa en una entrevista:

$\mathrm{Na}$ de oorlog had je een vrij bedompte samenleving, waarin de rancune ten opzichte van de Duitsers heel groot was. Alles wat Duits was,

neerlandesa de posguerra y, para el segundo, el libro de Rolf Wolfwinkel, que también analiza la literatura neerlandesa de posguerra, pero poniendo énfasis en la colaboración y traición de los neerlandeses durante la ocupación alemana. Cfr.: T. Anbeek, Na de oorlog. De Nederlandse roman 1945-1960, Amsterdam, De Arbeiderspers, 1986; R.. Wolfwinkel, Tussen vaderlandsliefde en landverraad. De collaboratie in naoorlogse proza, Amsterdam, Amsterdam University Press, 1994.

${ }^{3}$ N. Noordervliet, De naam van de vader, Amsterdam, Meulenhoff, 1993.

${ }^{4}$ N. Noordervliet, Het oog van de engel, Amsterdam, Meulenhoff, 1991: "El ojo del ángel”.

5 Ibid., 213: "Me rebelo contra el espíritu de la masa. ¿Quién asume la culpabilidad en una masa? ¿Quién es responsable? Todos y por ello nadie. Ese es el peligro.” 
werd veroordeeld, kinderen die op één of andere manier met Duitsland te maken hadden, kregen de last van die uitgesproken vijandigheid te dragen. ${ }^{6}$

La importancia de la obra De naam van de vader (1993) en la producción de Noordervliet es fundamental, por lo que se pretende hacer en este artículo un análisis que demuestre cómo elabora el tema de la Segunda Guerra Mundial literariamente. Teniendo claro que los alemanes sufrieron también durante y después de la Segunda Guerra Mundial, lo principal para Noordervliet es investigar a los culpables de estos terribles acontecimientos de forma concreta e individual.

En la novela De naam van de vader Nelleke Noordervliet se formula explícitamente preguntas sobre la culpabilidad y responsabilidad ante determinados hechos e investiga las relaciones entre el individuo y la sociedad occidental moderna, manteniendo como telón de fondo la Segunda Guerra Mundial. Existe una clara inquietud por parte de la autora de investigar intelectualmente la Segunda Guerra Mundial y, en concreto, la participación de Alemania y los alemanes. Este tema de la culpabilidad es, según el crítico Ian Buruma, una preocupación típica de la generación del 68, a la que Nelleke Noordervliet dice pertenecer ideológicamente. ${ }^{7}$ Por ello, afirma que su inquietud es: “(...) de moralistische preoccupatie met schuld die zoveel intellectuelen van de generatie van '68 kwelt." 8

De naam van de vader es una novela en la que determinados acontecimientos históricos desempeñan un papel importante: las consecuencias de la Segunda Guerra Mundial, los años sesenta y los cambios más recientes ocurridos en Europa conforman el trasfondo del libro. Cada tragedia personal se pone en relación con hechos históricos, sobre todo con acontecimientos de los años 1945, 1968 y 1989. La historia sirve, así, para entender mejor la propia historia personal. En este aspecto fundamental se descubre una clara influencia de la emblemática novela De Aanslag (1981) de Harry Mulisch, quien se centra igualmente en la historia mundial para desentrañar aspectos de una biografía personal. En este proceso las cuestiones sobre la culpabilidad y la responsabilidad son igualmente fundamentales

La primera parte de la novela, titulada Het woord (La palabra), ofrece una introducción en la que se narra la trayectoria vital de la protagonista, Augusta, fruto de una breve relación amorosa entre su madre, neerlandesa, y un soldado alemán durante el último año de la Segunda Guerra Mundial. El hecho de ser hija de una relación

\footnotetext{
6 Nelleke Noordervliet en una entrevista por televisión (satélite), verano 2003 (BVN): "Después de la guerra había una sociedad bastante maloliente, en la que el rencor con respecto a los alemanes era muy grande. Todo lo que era alemán, se desaprobaba, niños que de una u otra manera tenían que ver con Alemania, tenían que soportar esa enemistad explícita."

${ }^{7}$ I. Buruma, Het loon van de schuld, Amsterdam/Antwerpen, Uitgeverij Atlas, 1994, p. 242.

8 Ibid, p. 242: “(...) la preocupación moral por la culpabilidad que atormentaba a tantos intelectuales de la generación del 68."
} 
ilícita con un $m f^{9}$, palabra utilizada en neerlandés para insultar a los alemanes, la convierte en un moffenkind (hija de un mof) para muchos neerlandeses. Se menciona en el texto el hecho de que algunas madres prohibieran que sus hijos se relacionaran con moffenkinderen (hijos de moffen). Un ejemplo de ello, al comienzo de la novela, pone de manifiesto la voluntad de denuncia de la autora ante estos hechos. Una madre reprime a su hijo por jugar con la pequeña Augusta de esta manera: "Hé Robbie, wat is dat? Laat ik niet merken dat je met dat moffenkind omgaat. Weg jij. Ga naar je rotmoer, die stinkende moffenhoer."10 Además, dicho inocente personaje fue educado por un padrastro neerlandés sádico, que consideraba la existencia de Augusta como producto de una violación. Nadie le explicó nunca a la muchacha nada sobre su verdadero padre o sobre la relación que éste mantuvo con su madre. Ella se sintió durante años culpable por ser la hija de una relación con el enemigo, con un alemán. La autora refleja, de este modo, los crueles prejuicios y estereotipos de los neerlandeses con respecto a cualquier sujeto o elemento relacionado con Alemania.

El segundo capítulo de la novela, Het verborgen $V$ aderland, ${ }^{11}$ se centra en el viaje de Augusta, a la edad de 44 años ${ }^{12}$, para buscar a su padre. Se trata del verano previo a la caída del Muro en agosto de 1989. La mujer consigue fotos y documentos, en los que descubre el nombre de su padre, August Schultz, que por entonces - el último año de la guerra - vivía en Weimar. Con ayuda de unos amigos que desconocen sus verdaderos motivos, viaja a la antigua República Democrática de Alemania. Después de una larga búsqueda encuentra a la hermana de su padre y descubre que éste había muerto recientemente. Según el relato de la anciana su padre había sido un buen hombre, verdaderamente enamorado de su madre, pero resignado a la inevitable separación entre ellos, sobre todo ante las actitudes hostiles de los neerlandeses. La autora denuncia con esta trama argumental que el imaginario social de los neerlandeses era injustificadamente negativo. La sociedad neerlandesa seguía estando llena de prejuicios y estereotipos sobre Alemania y los alemanes. Además, Noordervliet invita

${ }^{9}$ El término mof influyó de una manera determinante desde el siglo XIX para identificar de una forma estereotipada a los alemanes con la burocracia, el militarismo y el espíritu sumiso. Durante el periodo en el que los Países Bajos estuvieron ocupados se confirmaron estos clichés para gran parte de la población neerlandesa. Es muy importante tener en cuenta aquí, especialmente a la hora de leer obras de autores neerlandeses que tienen como tema la Segunda Guerra Mundial, que, desde su liberación, los neerlandeses han recurrido sistemáticamente a estos estereotipos y prejuicios sobre los alemanes. Cfr.: Lademacher, H., Zwei ungleiche Nachbarn. Wege und Wandlungen der deutsch-niederländischen Beqiehungen im 19. und 20. Jahrbundert, Darmstadt, Wissenschaftliche Buchgesellschaft, 1990.

${ }^{10}$ N.Noordervliet, De naam van de vader, op.cit., p. 42: "Oye, Robbie, ¿Qué es eso? Que no me entere de que te juntas con la hija de un mof. Fuera tú. Vete con tu estúpida madre, esa puta de los moffen."

11 "La patria escondida."

${ }^{12}$ En 1989 la autora también tenía 44 años. 
a la reflexión sobre prejuicios y estereotipos que atañen incluso al ejército alemán. La mayoría de los soldados alemanes, según la autora, se alistaron al ejército de Hitler por obligación. Muchos de ellos eran ciudadanos convencionales que también sufrieron las consecuencias de la Segunda Guerra Mundial.

Otro personaje importante en la novela es Melchior, el marido de Augusta, medio judío. Este hombre, desaparecido de su vida desde hace ya más de diez años, sigue siendo oficialmente su marido. Fue un líder estudiantil, siempre presente en los lugares donde surgía algún movimiento revolucionario: en París y Praga, por ejemplo, en el año 1968. Augusta había sido su fiel compañera e interlocutora en numerosas discusiones sobre libertad y responsabilidad. Este estudiante revolucionario se casa con Augusta en el momento en que ella está embarazada. El niño nace en Praga, poco después de que los rusos invadieran esta ciudad, de la que ellos huyen por entonces precitadamente. Melchior es medio judío y tiene, como Augusta, un problema con su padre. En un principio el muchacho no sabe que Augusta, su joven mujer, era la hija de un soldado alemán. Al saberlo, la relación entre ambos empeora considerablemente. Traición, culpabilidad, venganza o sacrificio, son conceptos que adquieren en su relación un papel cada vez más importante. Las dificultades de esta relación ponen en evidencia que dichos prejuicios hacia los (soldados) alemanes no sólo estaban presentes en la sociedad neerlandesa, sino también entre los ciudadanos de otros países.

En el último capítulo del libro, Stirb und Werde, se revela que la muerte del hijo de Augusta, cuando el niño tenía sólo 5 años, así como la consiguiente desaparición de Melchior, son acontecimientos de su vida no asumidos ni superados. En Creta, donde Melchior lleva, en una casa totalmente aislada, una vida solitaria, sucede el feliz reencuentro de ambos.

Por otro lado, a lo largo de todo el texto la autora hace referencias a la caída del Muro y a la reunificación de Alemania. Estos acontecimientos históricos se presentan de una forma neutral, sin caer en estereotipos o prejuicios: se comunican a través de la radio y televisión. Así, mientras que Augusta está en un bar, escucha en la radio la siguiente noticia:

Dit is het nieuws van twaalf uur. Bondskanslier Helmut Kohl heeft tegenover een afvaardiging van het Oostduitse parlement verklaard dat de Bondsrepubliek er alles aan zal doen het proces van vernieuwing en democratisering te steunen door middel van investeringen. Eenwording van de beide Duitslanden zoals door demonstranten in grote Oostduitse steden wordt geëist, sluit hij op termijn niet uit $(. . .)^{13}$

${ }^{13}$ N. Noordervliet, De naam van de vader, op.cit., 1993, p. 33: "Estas son las noticias de las 12. El canciller alemán Helmut Kohl ha declarado ante una representación del parlamento de la RDA que la República Federal de Alemania va a hacer todo lo posible por apoyar el proceso de innovación y democratización mediante inversiones. La unificación de ambas Alemanias tal 
El dueño del bar, reacciona ante la noticia, secundando la opinión de muchos neerlandeses a raíz de la caída del muro. El personaje afirma: "Straks is dat land ze weer te klein, dan mot Polen er weer bij en Oostenrijk en wij." ${ }^{14}$ Pero también la protagonista, Augusta, ve peligro en una Alemania unificada. El miedo ante un imperio alemán poderoso, representa así el estereotipo de un país que necesita espacio vitalLebensraum, visto a través de los ojos de unos neerlandeses cargados de prejuicios contra Alemania y los alemanes. Además de este sentimiento de miedo, Nelleke Noordervliet describe también la arrogancia de muchos ciudadanos europeos, que se sienten superiores y fuertes dentro de su libertad, pero que en realidad sólo expresan una opinión impuesta:

Guus (...) luisterde naar de losse opmerkingen van enthousiasme en verbazing, het commentaar van de gemiddelde Westeuropeaan die zich koesterde in een grenzeloos gelijk, alsof in het debat de sterkste argumenten hadden gewonnen. Voor achterdocht en zelfonderzoek was geen plaats, waar het gelegitemeerde denken regeerde. In pasklare formules werd gedicteerd welke mening aanbevelingswaard was. ${ }^{15}$

En el segundo capítulo aparecen gran cantidad de imágenes de Alemania, que se refieren exclusivamente a la República Democrática. Hay numerosas opiniones y sentimientos, que se expresan a través de dichas imágenes. Por un lado, la mayoría de los ciudadanos de la antigua RDA se muestran satisfechos con respecto al cambio y esperan poder iniciar una vida mejor con la reunificación. Por otro lado, también parecen resentidos. El personaje de Eva recibe la siguiente respuesta cuando pide permiso para hacer una foto de una fábrica: "Grijp die kans, over een paar maanden liggen we plat. Waarom zijn wij opeens interessant? Omdat we een uitstervend ras zijn en onschadelijk? ${ }^{16}$ Más indicios de un cierto malestar quedan en evidencia, como el funcionamiento de la burocracia de la República Democrática de Alemania. Un ejemplo es la descripción que hace Eva de una funcionaria:

como es exigido por manifestantes en las grandes ciudades de la RDA, no se descarta dentro de un tiempo. (...)"

14 Ibid., p. 38: "Luego ese país es demasiado pequeño para ellos, entonces querrán también Polonia y Austria y a nosotros."

15 Ibid., p. 39: “Augusta (...) escuchaba las observaciones de entusiasmo y sorpresa, el comentario del europeo occidental medio, que consideraba tener una razón ilimitada, como si en el debate hubiesen ganado los argumentos más fuertes. No había lugar para la suspicacia y la autocrítica, gobernaba el pensamiento legitimado. Se dictaba, en fórmulas hechas a la medida, qué opinión era recomendable."

16 Ibid., p. 235: “Aprovecha esta oportunidad, dentro de unos meses estaremos parados. ¿Por qué de repente somos interesantes? ¿Porque somos una raza extinguida e inofensiva?” 
Het is een echte, dacht Guus, een echte door het systeem ontmenselijkte wandelende graftak, ze is de kleur van haar bureau, ze is de verveloosheid van de muren, ze is de geur van verstopte toiletten, ze is de absolute belediging van de allzumenschliche gevoelens waarmee ik hier voor haar sta. ${ }^{17}$

Además se repite la frase de muchos funcionarios de la RDA: "wie niets heeft misdaan, heeft niets te vrezen." 18

La actitud de los jóvenes en la Alemania del este no se describe, pues, positivamente. Cultivan la más absoluta desidia del "schijt aan alles"19, no tienen voluntad de cambiar nada. Ellos esperan que todo ocurra por sí mismo, conseguir una vida mejor sin hacer esfuerzo alguno. Esta indiferencia no es lo que Eva esperaba de la gente, ya que ella creía poder hacer fotos de la felicidad ideal, de un pueblo satisfecho que describe así:

(...) arbeiders en hun smerige fabrieken, een glinstering van hoop in hun bevrijde ogen, een schouders-eronder-blik, en tegelijkertijd een houding die schaamte uitdrukt om de verwording van een ideaal, een trotse jonge ondernemer die kapotte tractoren repareert en zodoende letterlijk op de puinhopen van het reëel existerende socialisme de basis legt voor de nieuwe welvaart van een heel dorp. ${ }^{20}$

Sin embargo, la realidad es muy diferente a sus expectativas y ella no consigue encontrar el ideal que tenía sobre los obreros de la antigua RDA. Lo único que ve es la grisáeca realidad:

De flats zagen eruit of ze kort voor de voltooing waren betrokken en met opzet versneld verouderd. Hier en daar stonden roestige speeltuigen op levensgevaarlijke betonnen sokkels; er groeide gras en onkruid tussen de stenen. Vuile bergen sneeuw lagen op dooi te wachten. ${ }^{21}$

17 Ibid., p. 122: "Es una de verdad, pensó Augusta, una verdadera tumba andante y deshumanizada por el sistema, ella es del color de su escritorio, ella es el aburrimiento de las paredes, ella es el olor de servicios atascados, es el insulto absoluto de los sentimientos allzumenschlich con los que me encuentro delante de ella."

18 Ibid., p. 232: "Quien no haya hecho nada malo, no tiene por qué temer."

19 Ibid., p. 52.: "Todo es una mierda"

20 Ibid., p. 88: “(...) trabajadores y sus sucias fábricas, un brillo de esperanza en sus ojos liberados, una mirada de arrimar el hombro, y al mismo tiempo una actitud que expresa vergüenza por la realización de un ideal, un empresario joven que repara tractores rotos y pone así la base sobre las ruinas del socialismo realmente existente para la nueva prosperidad de un pueblo entero."

${ }^{21}$ Ibid., p. 132: "Los pisos parecían como si poco antes de terminarse hubiesen sido cubiertos y envejecidos a propósito aceleradamente. Aquí y allá se encontraban aparatos herrumbrosos 
En general podemos afirmar que las imágenes de la antigua RDA son realmente decepcionantes. La experiencia en la antigua RDA de los diferentes personajes supone una confrontación con ideales perdidos, sueños rotos y la más absoluta desesperanza. En realidad no se critica aquí a la población de Alemania del este, sino al sistema comunista que ha provocado tal situación.

Aunque Nelleke Noordervliet describe las imágenes negativas de Alemania desde la perspectiva de los ciudadanos neerlandeses, cargados de prejuicios con respecto a los habitantes del país vecino, aparecen también otras imágenes más matizadas, expresadas igualmente por compatriotas. El tío de la protagonista es un ejemplo de esta postura más cabal. Éste cuenta a Augusta, cuando todavía era una niña, la historia de la guerra de una forma matizada, e intenta ofrecer otras imágenes de los alemanes: "Die Duitsers wisten natuurlijk ook wel dat de mensen hier niet zomaar zouden luisteren, hoewel ook veel mensen het helemaal niet erg vonden dat de Duitsers hier waren. En niet alle Duitsers waren slecht." 22 Esta actitud es interesante, puesto que al mismo tiempo que el tío de Augusta intenta matizar las imágenes negativas de los alemanes, aún firmes en muchos neerlandeses, se relativizan también las imágenes que los neerlandeses tienen de sí mismos con respecto a este tema. El personaje concluye que a muchos de ellos no les importaba la presencia alemana en los Países Bajos durante la Segunda Guerra Mundial. No obstante este hecho, la mayoría de los neerlandeses se aferraba a la idea de que la gran mayoría de la población luchaba en la resistencia neerlandesa o bien la apoyaba. La realidad histórica era, sin embargo, bien distinta: de todos los países ocupados por la Alemania nazi, los neerlandeses fueron los que más se alistaron voluntariamente en la Waffen-SS. Así lo explica el historiador neerlandés Sytze van der Zee:

Van alle bezette landen heeft Nederland het relatief grootste contingent van alle Waffen-SS-vrijwilligers geleverd. Naar de laatste schatting hebben tussen de 22.000 en 23.000 jonge Nederlandse mannen het 'feldgraue' SS-uniform gedragen. $\mathrm{Na}$ de oorlog hebben enkele hoge SSofficieren beweerd dat het zelfs meer dan 70.000 Nederlanders waren, maar dit aantal lijkt sterk overdreven. Maar 22.000 of 70.000 in beide gevallen hebben meer Nederlanders het Duitse 'feldgraue' gedragen dan het geallieerde kaki. ${ }^{23}$

sobre pedestales de hormigón muy peligrosos; crecía mala hierba entre las piedras. Sucios montones de nieve esperaban el deshielo."

22 Ibid., p. 44: "Esos alemanes naturalmente también sabían que la gente de aquí no les escucharía sin más, aunque a mucha gente tampoco les importaba que los alemanes estuviesen aquí."

23 S. Van der Zee, Voor Führer, volk en vaderland, Alphen aan den Rijn, Meulenhoff, 1991, contraportada: "De todos los países ocupados los Países Bajos han suministrado, en proporción, el contingente más grande de todos los voluntarios de las Waffen-SS. Según las 
Por otro lado, las características alemanas que se describen, están basadas en estereotipos y siempre desde la perspectiva de ciudadanos neerlandeses con prejuicios sobre los alemanes. La abuela de Augusta, por ejemplo, enumera rasgos típicos de los alemanes: "zwaarmoedig filosoferen (...) dwepen met gedichten (...) fanatisme voor actie en revolte (...) rigoureus, consequent, absoluut (...) perfectie in ontveinzing." 24 Además, la anciana afirma que, puesto que su nieta es medio alemana, posee una disciplina que le ha dado sus frutos: es licenciada y tienen un buen puesto de trabajo. Es decir, para la abuela, todas las características que supone típicamente alemanas, se encuentran en cualquier alemán, incluso en su nieta por haber tenido un padre de esta nacionalidad.

Por último, se hacen interesantes referencias en la obra a la lengua alemana. Para Augusta la lengua alemana suena terrible, tal como exclama ella: "De taal! dacht Augusta. Als ze hier was opgegroeid waren dit vertrouwde klanken. Nu raspten ze in haar oren." 25 Por otro lado, Eva piensa, indirectamente, que esta lengua representa un principio perdedor:

Doordat de voertaal Engels was en zij die lingua franca beter beheerste dan haar opponent, liep zij de achterstand in, voelde zij zich zelfs zijn meerdere: zij sprak in alle opzichten de taal van het winnende principe" 26

Por tanto, en De naam van de vader las imágenes de Alemania se presentan, en su mayor parte, como estereotipos y prejuicios, pero siempre bajo el punto de vista de los neerlandeses y sus prejuicios. Se trata de estereotipos del alemán violento, guerrero, disciplinado, nacionalista, fanático, con una lengua disonante, en suma, un pueblo que representa la barbarie. Sin embargo, la autora pone empeño en demostrar que esa actitud debe cambiar. Por ello deja claro que el padre de Augusta era un ex-soldado alemán con un buen corazón, que realmente amaba a su madre. Además, insiste en mencionar el hecho de que también los alemanes sufrieron durante la Segunda Guerra

últimas estimaciones entre 22.000 y 23.000 hombres neerlandeses jóvenes han llevado puesto el uniforme feldgrau de las SS. Después de la guerra han afirmado varios altos cargos de los oficiales de las SS que habían sido incluso más de 70.000 neerlandeses, pero esa cifra parece ser muy exagerada. Pero 22.000 o 70.000 , en ambos casos han llevado más neerlandeses puesto el 'feldgraue' alemán que el caqui aliado."

24 Ibid., p. 126: "filosofar de forma sombría (...)idolatrar sus poemas (...) fanatismo para la acción y la revuelta (...) rigurosos, consecuentes, absoluta (...) perfección en el disimulo."

25 Ibid., p. 240: “iLa lengua! Pensaba Augusta. Si hubiera crecido aquí habrían sido sonidos familiares. Ahora arañaban sus oídos."

${ }^{26}$ Ibid. Pp. 133, 134: "Puesto que el inglés era la lengua oficial y ella dominaba esa lengua franca mejor que su oponente, ella recuperaba el retraso, ella se sentía incluso su superior: ella hablaba en todos los sentidos la lengua del principio ganador." 
Mundial. En definitiva, la autora abre nuevas perspectivas en la consideración de los vecinos alemanes, tal como ella misma admite en una entrevista:

Ik weet niet of dat toeval is. Misschien heeft zoiets in de lucht gehangen, als een soort tweede generatieproblematiek. Nu wij allemaal wat ouder beginnen te worden gaan we, denk ik, onze verhoudingen met Duitsland opnieuw bezien. We leven in een tijd waarin ons oude vijandbeeld aan gruzelementen is gesmeten. Kennelijk past daarin dat we ook andere vijandbeelden, zoals bijvoorbeeld onze kijk op Duitsland, kritisch wegen. ${ }^{27}$

De todo ello se puede concluir que Nelleke Noordervliet se centra en su novela $D e$ naam van de vader en los temas de la culpabilidad y la responsabilidad en su dimensión individual. Culpar a todo un pueblo por lo ocurrido en la Segunda Guerra Mundial, se revela como una tarea estéril, por lo que la autora matiza las imágenes de Alemania con sumo cuidado. Tras la reunificación la crítica hacia los alemanes orientales y hacia la Alemania del Este se basa más bien en la descalificación del sistema comunista, que gobernó durante tantos años, no así contra sus habitantes. Por otro lado, los neerlandeses, que aparecen en un segundo plano en la obra, ven a los alemanes como violentos guerreros y Noordervliet los compara a menudo con los nacionalsocialistas. Existe, pues, también, una crítica a la sociedad neerlandesa por cultivar determinados prejuicios y estereotipos sobre los alemanes y Alemania.

Es preciso llamar la atención, sin embargo, sobre otra cuestión. A pesar de que Nelleke Noordervliet hace notar el error que supone equiparar a determinados individuos con todo un pueblo, ella cae en dicho error con los neerlandeses de la novela: apenas aparecen neerlandeses libres de prejuicios o estereotipos sobre los alemanes, lo cual tampoco es fiel reflejo de la realidad. Si bien es verdad que numerosos neerlandeses han mantenido ideas simplificadas sobre Alemania y los alemanes, la mayoría de ellos no sienten, así los datos de 199328 , dichos prejuicios. Concluyendo, podemos afirmar que en De naam van de vader se reflejan unas imágenes de Alemania cuidadosamente matizadas, aun a costa de unas imágenes de los neerlandeses muy negativas. Nelleke Noordervliet añade una nueva variante a la galería de personajes en la literatura neerlandesa contemporánea, la del estereotipo del neerlandés que odia a los alemanes y Alemania.

${ }^{27}$ Ibid., p. 78: "No sé si es casualidad. Tal vez había algo así en el el aire, como una especie de problemática de segunda generación. Ahora que todos nosotros nos estamos haciendo mayores vamos considerando nuevamente, pienso, nuestras relaciones con Alemania. Vivimos en una época en la que nuestra imagen del enemigo se ha roto en pedazos. Obviamente encaja aquí que reconsideremos de forma crítica también otras imágenes de enemigos, como por ejemplo nuestra visión de Alemania."

${ }^{28}$ Fuente: Eurobarometer, Beirat: Deutschland, 1995, p. 81. En este estudio se refleja que los neerlandeses confiaban sobre todo en sí mismos, pero la confianza en los alemanes alcanza el tercer puesto en 1993, por delante de los franceses, americanos, italianos o españoles. 


\section{REFERENCIAS BIBLIOGRÁFICAS.}

ANBEEK, T., Geschiedenis van de literatuur in Nederland 1885-1985, AmsterdamAntwerpen, De Arbeiderspers, 1990.

ANBEEK, T., Na de oorlog. De Nederlandse roman 1945-1960, Amsterdam, De Arbeiderspers, 1986.

BURUMA, I., Het loon van de schuld, Amsterdam/Antwerpen, Uitgeverij Atlas, 1994

LADEMACHER, H., Zwei ungleiche Nachbarn. Wege und Wandlungen der deutschniederländischen Beziebungen im 19. und 20. Jabrbundert, Darmstadt, Wissenschaftliche Buchgesellschaft, 1990.

NOORDERVLIET, N., De naam van de vader, Amsterdam, Meulenhoff, 1993.

NOORDERVLIET, N., Het oog van de engel, Amsterdam, Meulenhoff, 1991.

VAN DER ZEE, S., Voor Führer, volk en vaderland, Alphen aan den Rijn, Meulenhoff, 1991.

WOLFWINKEL, R., Tussen vaderlandsliefde en landverraad. De collaboratie in naoorlogse proza, Amsterdam, Amsterdam University Press, 1994.

Manuel Sánchez Romero

masanchezro@us.es

Departamento de Filología Alemana

Facultad de Filología

Universidad de Sevilla

C/Palos de la Frontera, 1

E-41004 Sevilla (Spain)
Fecha de recepción: 24/10/2007

Fecha de aceptación: 12/04/2007 